\title{
The Effect of Supplementation of Organic Copper to Commercial Quail Diets on Performance, Egg Quality and Haematological Parameters
}

\author{
Osman Olgun ${ }^{1, a}$, Alpönder Yıldız ${ }^{1, b, *}$, Esra Tuğçe Şentürk ${ }^{1, c}$ \\ ${ }^{1}$ Department of Animal Science, Faculty of Agriculture, Selcuk University, 42130 Konya, Turkey \\ *Corresponding author \\ A R T I C L E IN F O A B S T R A C T \\ Research Article \\ The aim of this study was to investigate the effects of organic copper supplementation $(0,5,10$ and \\ $20 \mathrm{mg} / \mathrm{kg}$ ) in the commercial diet on performance, egg quality and haematological parameters in \\ laying quails. In this 10 -week trial, a total of 80 laying quails, aged 22 weeks, were randomly \\ distributed among four experimental groups. Each experimental group contained four replicates of \\ Received : 18/02/2020 \\ Accepted : 03/03/2020 \\ five female birds each. The addition of organic copper to the diets did not statistically affect egg \\ production, egg weight, egg mass, feed conversion ratio, damaged eggs, egg shape index, Haugh \\ unit, and blood parameters except neutrophils and mean corpuscular haemoglobin. Compared to \\ other groups, body weight change was decreased by the addition of $20 \mathrm{mg} / \mathrm{kg}$ organic copper, and \\ feed intake was decreased by the addition of $10 \mathrm{mg} / \mathrm{kg}$ copper in the quails. The addition of 20 \\ $\mathrm{mg} / \mathrm{kg}$ of organic copper to the quail diets significantly decreased the eggshell breaking strength \\ Keywords: \\ Egg quality \\ Haematology \\ Performance \\ Organic copper \\ Quail \\ and eggshell weight, while it significantly increased the eggshell thickness compared with the \\ control group. The neutrophil and mean corpuscular haemoglobin were increased by the addition \\ of 10 and $20 \mathrm{mg} / \mathrm{kg}$ organic copper, respectively, with compare to other groups. It can be said that \\ up to $10 \mathrm{mg} / \mathrm{kg}$ of organic copper can be added to commercial quail diets, but its addition at 20 \\ $\mathrm{mg} / \mathrm{kg}$ negatively effects on some blood parameters as neutrophil and mean corpuscular \\ haemoglobin in quails.
}

\section{Introduction}

The copper $(\mathrm{Cu})$ is an essential element in poultry nutrition. The copper is required for the use of iron in haemoglobin synthesis, it is take part in the different enzyme systems such as cytochrome A, catalase, thyrosinase, monoamine oxidase, ascorbic acid oxidase, uricase, superoxide dismutase, lysyl oxidase, dopamine hydroxylase, ceruloplasmin or it is provide the activation these enzymes as a cofactor (Wedekind et al. 1992; İpek et al. 2003). It is one of the essential trace minerals for healthy growth, development and metabolic functions of living organism (Kozlowski et al. 2018).

Inorganic sources such as sulphate, which is a cheap source of $\mathrm{Cu}$, are used in poultry diets. However, organic sources of $\mathrm{Cu}$, such as amino acids or complex chelates, are absorbed more effectively from inorganic salts in the intestines (Wedekind et al. 1992; Aoyagi and Baker 1993). Therefore, as in other elements, the inorganic form of $\mathrm{Cu}$ is low in absorption and accumulates as a contaminant in soil and ground water because it is excreted with faces.
Since the absorption of organic $\mathrm{Cu}$ sources from the intestine is higher than inorganic sources, both the amount added to the diet and the amount excreted with the faces are less compared with inorganic sources (Bao et al. 2007; Gupta and Charles 1999). Therefore, the use of organic sources of $\mathrm{Cu}$ is important not only for poultry nutrition, but also for the environment.

Copper requirement of quails was reported as $5 \mathrm{mg} / \mathrm{kg}$ by NRC (1994). There were studies reported that the supplementation of high levels of $\mathrm{Cu}$ to layer diets was improved (Abaza et al. 2009; Olgun et al. 2013; Kaya et al. 2018) or deteriorated (Mendonca et al. 1999; Tekeli et al. 2005) performance and eggshell quality in birds. Kaya et al. (2018) showed that the addition of 200, 250 and 300 $\mathrm{mg} / \mathrm{kg}$ levels of $\mathrm{Cu}$ to the diet decreased egg weight and feed intake in laying hens but increased eggshell resistance. Olgun and Aygun (2017) stated that the addition of $\mathrm{Cu}(150$ or $300 \mathrm{mg} / \mathrm{kg}$ ) to the diet improved the performance parameters of laying hens and decreased the eggshell 
weight. However, the Cu levels (from 50 to $800 \mathrm{mg} / \mathrm{kg}$ ) in these studies are quite high. In addition, the number of studies investigating the effect of addition of low levels $\mathrm{Cu}$ is also very limited, especially the effects in quails or on haematological parameters.

In the light of these findings, the aim of this study was to investigate the effects of supplementation different levels organic $\mathrm{Cu}$ to diets on performance, egg quality parameters and haematological in quails.

\section{Material and Method}

In this study, a total of 80 female Japanese quails at the age of 22 weeks have been randomly distributed among four treatment groups and has lasted 10 weeks. In each treatment group, there have been four replicates, each with five quail. For 10 weeks, the quails were fed four experimental diets containing four levels $(0,5,10$ and 20 $\mathrm{mg} / \mathrm{kg}$ ) of $\mathrm{Cu}$ as $\mathrm{Cu}$ propionate. The experimental diets were balanced to meet or exceed the nutrient requirements of the Japanese quail (NRC 1994). The control diet and its calculated nutrient contents are shown in Table 1. During the experiment, water and feed were given as ad libitum.

\section{Performance Parameters}

Body weight change (BWC), was obtained by group weighing of the quails in the beginning and final of experiment. Feed intake (FI) was calculated at the final of research. Egg production (EP) was recorded daily. Egg weight (EW) was found out by weighing all eggs collected at last two days of research. Egg mass was calculated with $\mathrm{EM}=(\mathrm{EP}(\%) \times \mathrm{EW}) / 100$ formula. Feed conversion ratio (FCR) was obtained from FCR= FI (g/feed/quail)/EM (g/egg/quail).

\section{Egg Quality Parameters}

Related measurements about of eggshell quality (membrane eggshell weight (\%), membrane eggshell thickness and eggshell strength) and Haugh unit parameters were made on the all eggs collected at last two days of treatment. Length and diameter of each egg were determined by digital calliper. Egg shape index was calculated with egg diameter/egg length $\times 100$ formula by using these parameters. Eggshell strength was measured by applying supported systematic pressure to blunt of the eggs (Egg Force Reader, Orka Food Technology, Israel).
Subsequently, albumin height has been determined with digital height gauge. Haugh unit was calculated as follows: Haugh unit $=100 \times \log ($ albumin height $+7.57-1.7 \times$ $\mathrm{EW}^{0.37}$ ) (Haugh 1937). Membrane eggshell weight rate was determined by using eggshell weight $(\mathrm{g}) / \mathrm{egg}$ weight $(\mathrm{g}) \times$ 100 formula. The membrane eggshell thickness was calculated from the values obtained with digital calliper from three sections of the eggs. The egg quality analyses were completed within 24 hours after eggs were collected.

\section{Haematological Analysis}

At the end of the study, the bloods were taken into heparinised tubes by entering with syringe to the heart of randomly selected one quail each replicate (four quail per treatment group) for haematological analysis. The bloods haematological analysis were made by auto-analyser according to Campbell (1988).

\section{Statistical Analysis}

At the end of the research, the variance analyses have been applied to all variables obtained from the trial groups (Minitab 2000), and the differences between means of the groups were determined by the Tukey multiple comparison test.

\section{Results and Discussion}

The effect of adding different levels of organic $\mathrm{Cu}$ to the diets on performance parameters in laying quails are demonstrated at Table 2. There have no significant differences among treatment groups for EP, EW, EM and FCR (P>0.05). In this study, BWC was significantly reduced by $20 \mathrm{mg} / \mathrm{kg} \mathrm{Cu}$ supplementation with compared other groups $(\mathrm{P}<0.01)$. While the highest $\mathrm{BWC}$ was obtained at $5 \mathrm{mg} / \mathrm{kg}$, this difference has not statistically significant compared to the 0 or $10 \mathrm{mg} / \mathrm{kg} \mathrm{Cu}$ levels groups. At the final of experiment, the lowest FI shown in quails fed with diet added $10 \mathrm{mg} / \mathrm{kg}$ organic $\mathrm{Cu}$, and this statistically significant compared to other groups $(\mathrm{P}<0.05)$.

There have been studies, which investigated the effect of supplementation different levels $\mathrm{Cu}$ to diets on performance parameters. Contrary to the results obtained in the current research, in some studies, it was reported that the addition of $\mathrm{Cu}$ to diets of layers has not affect for BWC and FI (Ankari et al. 1998; Pesti and Bakalli 1998; Balevi and Coskun 2004; Azman and Y1lmaz 2005; Olgun et al. 2013).

Table 1. Control diet and its calculated nutrient contents

\begin{tabular}{l|rlr}
\hline \multicolumn{1}{c|}{ Ingredients } & $\%$ & \multicolumn{1}{c}{ Nutrient contents } & Value \\
\hline Corn & 54.20 & Metabolisable energy, kcal ME/kg & 2902 \\
Soybean meal & 27.00 & Crude protein, \% & 20.09 \\
Sunflowers meal & 7.00 & Calcium, \% & 2.51 \\
Vegetable oil & 4.30 & Available phosphorus, $\%$ & 0.35 \\
Limestone & 5.60 & Lysine, \% & 1.00 \\
Dicalcium phosphate & 1.15 & Methionine, $\%$ & 0.45 \\
Salt & 0.35 & Cystine, \% & 0.37 \\
Premix ${ }^{1}$ & 0.25 & Methionine+cystine, $\%$ & 0.82 \\
DL methionine & 0.15 & Copper, mg/kg & 35.95 \\
\hline Total & 100.00 & & \\
\hline
\end{tabular}

${ }^{1}$ Premix is provide that per $1 \mathrm{~kg}$ of diet; manganese: $80 \mathrm{mg}$, iron: $60 \mathrm{mg}$, copper: $5 \mathrm{mg}$; iodine, $1 \mathrm{mg}$, selenium: $0.15 \mathrm{mg}$, Vitamin A:8.800 IU, Vitamin $\mathrm{D}_{3}: 2.200 \mathrm{IU}$, Vitamin E: $11 \mathrm{mg}$, Nicotine acid: $44 \mathrm{mg}$, Cal-D-Pan: $8.8 \mathrm{mg}$, Riboflavin: $4.4 \mathrm{mg}$, Thiamine: $2.5 \mathrm{mg}$, Vitamin B $12.6 \mathrm{mg}$, Folic acid: 1 mg, Biotin: $0.11 \mathrm{mg}$, Choline: $220 \mathrm{mg}$. 
Table 2. Effects of supplementation different levels organic copper to diets on performance parameters in Japanese quails

\begin{tabular}{|c|c|c|c|c|c|c|}
\hline \multirow{2}{*}{ Parameters } & \multicolumn{4}{|c|}{ Organic $\mathrm{Cu}$ Levels } & \multirow{2}{*}{ SEM* } & \multirow{2}{*}{$\begin{array}{c}\mathrm{P} \\
\text { values }\end{array}$} \\
\hline & $0 \mathrm{mg} / \mathrm{kg}$ & $5 \mathrm{mg} / \mathrm{kg}$ & $10 \mathrm{mg} / \mathrm{kg}$ & $20 \mathrm{mg} / \mathrm{kg}$ & & \\
\hline BWC, g & $11.17^{\mathrm{A}}$ & $22.08^{\mathrm{A}}$ & $11.83^{\mathrm{A}}$ & $-8.00^{\mathrm{B}}$ & 3.564 & 0.001 \\
\hline $\mathrm{EP}, \%$ & 89.42 & 90.12 & 91.01 & 88.63 & 1.222 & 0.614 \\
\hline EW, g & 13.20 & 13.39 & 12.63 & 12.96 & 0.255 & 0.287 \\
\hline EM, g/d/quail & 11.80 & 12.06 & 11.49 & 11.49 & 0.270 & 0.435 \\
\hline FI, g/d/quail & $35.73^{\mathrm{a}}$ & $35.52^{\mathrm{a}}$ & $33.40^{\mathrm{b}}$ & $35.71^{\mathrm{a}}$ & 0.462 & 0.013 \\
\hline FCR, FI/EM & 3.03 & 2.95 & 2.91 & 3.12 & 0.059 & 0.134 \\
\hline
\end{tabular}

BWC: Body Weight Change, EP: Egg Production, EW: Egg Weight, EM: Egg Mass, FI: Feed Intake, FCR: Feed Conversion Ratio.*Standard error means, ${ }^{\mathrm{AB}}$ Values bearing different superscript in rows are statistically different; $\mathrm{P}<0.01$., ${ }^{\text {ab }}$ Values bearing different superscript in rows are statistically different; $\mathrm{P}<0.05$.

Table 3. Effects of supplementation different levels organic copper to diets on egg quality parameters in Japanese quails

\begin{tabular}{l|cccccc}
\hline \multirow{2}{*}{ Parameters } & \multicolumn{5}{c}{ Organic Cu Levels } & P \\
\cline { 2 - 5 } & $0 \mathrm{mg} / \mathrm{kg}$ & $5 \mathrm{mg} / \mathrm{kg}$ & $10 \mathrm{mg} / \mathrm{kg}$ & $20 \mathrm{mg} / \mathrm{kg}$ & & values \\
\hline Damaged Eggs, \% & 0.00 & 0.68 & 0.00 & 0.30 & 0.111 & 0.058 \\
Egg Shape Index & 76.83 & 79.68 & 77.39 & 78.01 & 0.996 & 0.397 \\
Eggshell Breaking Strength, kg & $1.57^{\mathrm{A}}$ & $1.62^{\mathrm{A}}$ & $1.51^{\mathrm{AB}}$ & $1.37^{\mathrm{B}}$ & 0.041 & 0.010 \\
Eggshell Weight, \% EW & $7.90^{\mathrm{A}}$ & $7.84^{\mathrm{AB}}$ & $8.19^{\mathrm{A}}$ & $7.34^{\mathrm{B}}$ & 0.111 & 0.003 \\
Eggshell Thickness, $\mu \mathrm{m}$ & $194.00^{\mathrm{B}}$ & $202.75^{\mathrm{AB}}$ & $202.25^{\mathrm{AB}}$ & $208.25^{\mathrm{A}}$ & 1.838 & 0.010 \\
Haugh Unit & 76.15 & 75.56 & 71.07 & 73.96 & 1.488 & 0.190 \\
\hline
\end{tabular}

* Standard error means, ${ }^{\mathrm{AB}}$ Values bearing different superscript in rows are statistically different; $\mathrm{P}<0.01$.

Table 4. Effects of supplementation different levels organic copper to diets on some blood parameters in Japanese quails

\begin{tabular}{|c|c|c|c|c|c|c|}
\hline \multirow{2}{*}{ Parameters } & \multicolumn{4}{|c|}{ Organic $\mathrm{Cu}$ Levels } & \multirow{2}{*}{ SEM* } & \multirow{2}{*}{$\begin{array}{c}\mathrm{P} \\
\text { values }\end{array}$} \\
\hline & $0 \mathrm{mg} / \mathrm{kg}$ & $5 \mathrm{mg} / \mathrm{kg}$ & $10 \mathrm{mg} / \mathrm{kg}$ & $20 \mathrm{mg} / \mathrm{kg}$ & & \\
\hline $\mathrm{WBC}, 10^{3} / \mu \mathrm{l}$ & 15.05 & 15.57 & 11.82 & 15.50 & 1.303 & 0.307 \\
\hline $\mathrm{NEU}, 10^{3} / \mu \mathrm{l}$ & $0.76^{\mathrm{B}}$ & $1.01^{\mathrm{B}}$ & $1.67^{\mathrm{A}}$ & $0.91^{\mathrm{B}}$ & 0.108 & 0.001 \\
\hline $\mathrm{LYM}, 10^{3} / \mu \mathrm{l}$ & 15.61 & 14.47 & 11.74 & 10.55 & 1.746 & 0.334 \\
\hline $\mathrm{RBC}, 10^{6} / \mu \mathrm{l}$ & 3.19 & 3.18 & 3.39 & 2.65 & 0.213 & 0.207 \\
\hline $\mathrm{HGB}, \mathrm{g} / \mathrm{dL}$ & 17.73 & 17.63 & 17.25 & 16.23 & 0.495 & 0.313 \\
\hline HCT, $\%$ & 47.00 & 45.97 & 45.29 & 40.80 & 1.588 & 0.145 \\
\hline $\mathrm{MCV}, \mu \mathrm{m}^{3}$ & 148.00 & 145.33 & 146.81 & 154.00 & 2.088 & 0.107 \\
\hline $\mathrm{MCH}, \mathrm{pg}$ & $55.77^{\mathrm{B}}$ & $56.00^{\mathrm{B}}$ & $54.93^{\mathrm{B}}$ & $61.33^{\mathrm{A}}$ & 1.006 & 0.007 \\
\hline $\mathrm{MCHC}, \mathrm{g} / \mathrm{dL}$ & 37.73 & 38.60 & 38.73 & 39.83 & 0.440 & 0.086 \\
\hline RDW, \% & 10.23 & 10.30 & 10.34 & 11.23 & 0.376 & 0.335 \\
\hline $\mathrm{PLT}, 10^{3} / \mu \mathrm{l}$ & 7.69 & 10.67 & 5.51 & 12.62 & 2.259 & 0.247 \\
\hline HGB/LYM & 1.15 & 1.29 & 1.48 & 2.36 & 0.320 & 0.362 \\
\hline
\end{tabular}

WBC: White Blood Cell, NEU: Neutrophil, LYM: Lymphocyte, RBC: Red Blood Cell, HGB: Haemoglobin, HCT: Haematocrit, MCV: Erythrocyte Volume, MCH: Mean Corpuscular Haemoglobin, MCHC: Corpuscular Haemoglobin Concentration, RDW: Red Blood Cell Distribution Width, PLT: Thrombocyte, HGB/LYM: Haemoglobin/Lymphocyte Ratio., * Standard error means ${ }^{\mathrm{AB}}$ Values bearing different superscript in rows are statistically different; $\mathrm{P}<0.01$.

On the other hand, Kocaoğlu Güçlü et al. (2008) stated that the addition of 150 and $300 \mathrm{mg} / \mathrm{kg}$ levels of $\mathrm{Cu}$ as $\mathrm{Cu}$ proteinate to the diet increased the EP without affecting body weight and FI in laying hens. Similarly, Mendonca et al. (1999) investigated the effects of supplementation high levels $(400,600$ and $800 \mathrm{mg} / \mathrm{kg}$ ) of $\mathrm{Cu}$ to the diet. It was reported that the FI was not affected with the addition of $400 \mathrm{mg} / \mathrm{kg} \mathrm{Cu}$ in the diets. However, it decreased as the level of $\mathrm{Cu}$ increased. In addition to these, Idowu et al. (2006); Kaya et al. (2009) stated that the FI was decreased with the supplementation of $\mathrm{Cu}$ to the layer diets. In the current study, this decrease in FI of the $10 \mathrm{mg} / \mathrm{kg} \mathrm{Cu}$ group improved FCR numerically but is statistically insignificant.

The effect of supplementation different levels $\mathrm{Cu}$ to diets on egg quality parameters has been given at Table 3 . The results of the study showed that the treatments on the damaged eggs, egg shape index and Haugh unit parameters have not statistically significant $(\mathrm{P}>0.05)$. At the group supplemented $20 \mathrm{mg} / \mathrm{kg} \mathrm{Cu}$, eggshell breaking strength and eggshell weight were significantly decreased $(\mathrm{P}<0.01)$. While the highest eggshell breaking strength found at 5 $\mathrm{mg} / \mathrm{kg}$ level, the highest eggshell weight was obtained from the group added $10 \mathrm{mg} / \mathrm{kg} \mathrm{Cu}(\mathrm{P}<0.01)$. On the other hand, eggshell thickness parameter has been significantly increased at the $20 \mathrm{mg} / \mathrm{kg} \mathrm{Cu}$ unlike eggshell breaking strength and eggshell weight, and this raise has been found statistically significant compared to other $\mathrm{Cu}$ levels $(\mathrm{P}<0.01)$. Also, eggshell thickness was statistically diminished at the control group compared to $20 \mathrm{mg} / \mathrm{kg}$ level $\mathrm{Cu}(\mathrm{P}<0.01)$.

Mendonca et al. (1999) and Tekeli et al. (2005) reported that the decreased of eggshell breaking strength and eggshell weight with supplementation from 75 to 800 $\mathrm{mg} / \mathrm{kg} \mathrm{Cu}$ to diets. These study results agree with the current study results. On the contrary, there are also research which stated Kaya et al. (2009) and Olgun et al. (2012) found out that the addition of $\mathrm{Cu}$ to the diets improved eggshell strength. In addition to, Idowu et al. 
(2006) demonstrated that the supplementation of $\mathrm{Cu}$ to layer diets was not affected. Brodacki et al. (2018) stated that the addition of $30 \mathrm{mg} / \mathrm{L} \mathrm{Cu}$-lysine as an organic source to drinking water increased the eggshell weight without affecting the eggshell resistance and thickness.

The effect of adding different levels $\mathrm{Cu}$ to diets on some blood parameters is demonstrated at Table 4. According to these results, there were no significant differences among treatment groups in terms of white blood cell (WBC), lymphocyte (LYM), red blood cell (RBC), haemoglobin (HGB), haematocrit (HCT), erythrocyte volume (MCV), corpuscular haemoglobin concentration (MCHC), red blood cell distribution width (RDW), thrombocyte (PLT) parameters and haemoglobin/lymphocyte ratio (HGB/LYM) (P>0.05). However, neutrophil (NEU) has significantly risen with 10 $\mathrm{mg} / \mathrm{kg}$ level $\mathrm{Cu}$ compared to other treatment groups $(\mathrm{P}<0.01)$. The lowest NEU obtained from the control group but this different has insignificant compared with $5 \mathrm{mg} / \mathrm{kg}$ and $20 \mathrm{mg} / \mathrm{kg}$ levels. In addition, mean corpuscular haemoglobin $(\mathrm{MCH})$ was significantly increased at the 20 $\mathrm{mg} / \mathrm{kg}$ level $(\mathrm{P}<0.01)$ with compared the other groups. The result agree with the findings of Sharma et al. (2009), who stated that orally administered in a dose of $2 \mathrm{mg} /$ day $\mathrm{Cu}$ in male chicks increased whole blood, erythrocytes and $\mathrm{MCH}$, but did not affect other blood parameters. In addition, İpek et al. (2003) reported that the supplementation of 50 and $150 \mathrm{mg} / \mathrm{kg}$ levels of $\mathrm{Cu}$ to the laying quail diets has not affect some haematological parameters. El-Ghalid et al. (2019) showed that the addition of 50 and $100 \mathrm{mg} / \mathrm{kg}$ of organic $\mathrm{Cu}(\mathrm{Cu}-$ methionine or $\mathrm{Cu}$-glycine) to the diet significantly increased blood haematological (RBC, HGB, WBC and LYM) parameters in broilers compared to the control or inorganic $\mathrm{Cu}$ supplement groups. The reason for the decrease in body weight change, eggshell resistance and eggshell weight may be the high MHC caused by $\mathrm{Cu}$, and other parameters may also be thought to decrease in time at high $\mathrm{Cu}$ levels or longer trial periods.

There are differences among the results of the studies examined the effects of sources and levels of $\mathrm{Cu}$ on performance and eggshell quality in layer birds. Therefore, further studies have been required the more long-termed and detailed with different sources and levels of $\mathrm{Cu}$ to understand effects on the performance and eggshell parameters in poultry.

The addition of $20 \mathrm{mg} / \mathrm{kg}$ (total $56 \mathrm{mg} / \mathrm{kg} \mathrm{Cu}$ in the diet) organic $\mathrm{Cu}$ to the diet negatively affected the eggshell quality and some blood parameters of layer quails. According to the results obtained from the trial, it can be said that the most suitable $\mathrm{Cu}$ level in laying quail diets is $10 \mathrm{mg} / \mathrm{kg}$.

\section{References}

Abaza I, Ezzat W, Shoeib M, El-Zaiat A, Hassan I. 2009. Effects of copper sulfate on productive, reproductive performance and blood constituents of laying Japanese quail fed optimal and sub-optimal protein. International Journal of Poultry Science, 8: 80-89.

Ankari A, Najib H, Al Hozab A. 1998. Yolk and serum cholesterol and production traits, as affected by incorporating a supra optimal amount of copper in the diet of the leghorn hen. British Poultry Science, 39: 393-397.
Aoyagi S, Baker DH. 1993. Nutritional evaluation of copperlysine and zinc-lysine complexes for chicks. Poultry Science, 72: 165-171. doi: 10.3382/ps.0720165

Azman MA, Yılmaz M. 2005. Etlik piliç rasyonlarına katılan bakır sülfat'ın performans ve bazı kan parametreleri üzerine etkisi. Fırat Üniversitesi Doğu Araştırmaları Dergisi, 4: 2326.

Balevi T, Coskun B. 2004. Effects of dietary copper on production and egg cholesterol content in laying hens. British Poultry Science, 45: 530-534. doi: 10.1080/000716604 12331286253

Bao YM, Choct M, Iji PA, Bruerton K. 2007. Effect of organically complexed copper, iron, manganese, and zinc on broiler performance, mineral excretion, and accumulation in tissues. Journal of Applied Poultry Research, 16: 448-455.

Brodacki A, Batkowska J, Stepniowska A, Blicharska E, Drabik K. 2018. Quality and mineral composition of eggs from hens supplemented with copper-lysine chelate. Archives Animal Breeding, 61: 109-113. doi: 10.5194/aab-61-109-2018

Campbell TW. 1988. Avian Hematology and Cytology. State University Press.

El-Ghalid OAH, El-Ashry GM, Soliman SM, Abd El-Hady AM. 2019. Effect of dietary sources and levels of copper supplementation on growth performance, blood parameters and slaughter traits of broiler chickens. Egyptian Poultry Science, 39: 897-912. doi: 10.21608/EPSJ.2019.67513

Gupta G, Charles S. 1999. Trace elements in soils fertilized with poultry litter. Poultry Science, 78: 1695-1698. doi: $10.1093 / \mathrm{ps} / 78.12 .1695$

Haugh R. 1937. The Haugh unit for measuring egg quality. United States Egg and Poultry Magazine, 43: 522-555.

Idowu O, Laniyan T, Kuye O, Oladele-Ojo V, Eruvbetine D. 2006. Effect of copper salts on performance, cholesterol, residues in liver, eggs and excreta of laying hens. Archivos de Zootecnica, 55: 327-338.

İpek H, Yertürk M, Avc1 M. 2003. Yumurtlama dönemindeki bildırcın karma yemlerine farklı oranlarda çinko ve bakır ilavesinin yumurta verim özellikleri ile bazı kan parametreleri üzerine etkisi. Yüzüncü Y1l Üniversitesi Veteriner Fakültesi Dergisi, 14: 65-68.

Kaya A, Kaya H, Macit M, Aksu M, Kaynar Ö, Çelebi Ş, Karaoglu M. 2009. Yumurtacı tavuk rasyonlarına farklı seviyelerde bakır ilavesinin performans, yumurta kalitesi ve lipid metabolizması üzerine etkisi. 6. Ulusal Zootekni Bilim Kongresi, 2009. 24-26 Haziran, Erzurum, pp. 161.

Kaya H, Kaya A, Macit M, Kaynar Ö. 2018. Effects of dietary copper supplementation on performance, egg quality parameters, yolk cholesterol and fatty acid profiles in laying hens. Indian Journal of Animal Research, 52: 1623-1627. doi: 10.18805/ijar. B-830

Kocaoğlu Güçlü B, Kara K, Beyaz L, Uyanik F, Eren M, Atasever A. 2008. Influence of dietary copper proteinate on performance, selected biochemical parameters, lipid peroxidation, liver, and egg copper content in laying hens. Biological Trace Element Research, 125: 160-169. doi: 10.1007/s12011-008-8164-1

Kozlowski K, Jankowski J, Otowski K, Zdunczyk Z, Ognik K. 2018. Metabolic parameters in young turkeys fed diets with different inclusion levels of copper nanoparticles. Polish Journal of Veterinary Sciences, 21: 245-253. doi: $10.24425 / 119043$

Mendonca CX, Watanabe C, Mori AV, Santos CDOF, Almeida CRM. 1999. Effects of high supplemental dietary copper on laying performance, egg yolk cholesterol and blood plasma lipids. Brazilian Journal of Veterinary Research and Animal Science, 36: 327-331.

Minitab I. 2000. MINITAB Statistical Software. Minitab Release $13,0$.

NRC. 1994. Nutrient Requirements of Poultry, 9th edition, National Academies Press: Washington, DC, USA. pp. 44-45. 
Olgun O, Yazgan O, Cufadar Y. 2012. Effects of boron and copper dietary supplementation in laying hens on eggshell quality, plasma and tibia mineral concentrations and bone biomechanical properties. Revue de Medecine Veterinaire, 163: 335-342.

Olgun O, Yazgan O, Cufadar Y. 2013. Effect of supplementation of different boron and copper levels to layer diets on performance, egg yolk and plasma cholesterol. Journal of Trace Elements in Medicine and Biology, 27: 132-136. doi: 10.1016/j.jtemb.2012.09.005

Olgun O, Aygun A. 2017. The effect of copper supplementation on performance, eggshell quality and heterophil:lymphocyte ratio in aged laying hens housed at different stocking densities. Animal Nutrition and Feed Technology, 17:25-33. doi: 10.5958/0974-181X.2017.00003.8
Pesti GM, Bakalli RI. 1998. Studies on the effect of feeding cupric sulfate pentahydrate to laying hens on egg cholesterol content. Poultry Science, 77: 1540-1545. doi: 10.1093/ps/77.10.1540

Sharma D, Kochar B, Bhardwaj A, Riyat M, Sharma P. 2009. Effect of ingestion of copper bhasm on red cell indices, iron parameters and essential elements in chicks. Indian Journal of Clinical Biochemistry, 24: 245-249.

Tekeli S, Öztabak K, Gürsel FE. 2005. Yumurtacı tavukların yemine yüksek dozda ilave edilen bakırın yumurta üretimi, yumurta kabuk ağırlığı ve yumurta kabuk kalınlığına etkisi. İstanbul Üniversitesi Veteriner Fakültesi Dergisi, 31: 177183.

Wedekind K, Hortin A, Baker D. 1992. Methodology for assessing zinc bioavailability: efficacy estimates for zincmethionine, zinc sulfate, and zinc oxide. Journal of Animal Science, 70: 178-187. doi: 10.2527/1992.701178x 